\title{
Cryopreservation triggers DNA fragmentation and ultrastructural damage in spermatozoa of oligoasthenoteratozoospermic men
}

\author{
Kriyopreservasyon oligoastenoteratozoospermik erkeklerde DNA fragmantasyonunu ve \\ ultrastrüktürel hasarı tetikler
}

Pınar TURAN, Gözde ERKANLI ŞENTÜRK, Feriha ERCAN

\begin{abstract}
Objective: Oligoasthenoteratozoospermia (OAT) is one of the causes of male infertility. Cryopreservation is valuable for the management of infertility. This study aimed to reveal the effects of cryopreservation on sperm motility, morphology, ultrastructural details and DNA fragmentation in patients with OAT.

Materials and Methods: In this observational study, ejaculates were collected from 40 male volunteers of whom 20 were OAT and 20 were normospermic. The ejaculates were stored in liquid nitrogen at $-196^{\circ} \mathrm{C}$ and analysed following thawing after 1 or 3 months. Ejaculates were evaluated in terms of motility, morphology and DNA fragmentation before and after thawing.

Results: Sperm motility and morphology were both affected by cryopreservation in samples from both groups. After thawing, spermatozoa with morphological abnormalities were increased significantly in both groups. Ultrastructural investigations showed alteration in integrity of the membranes and increased acrosomal defects. Post-thaw investigations revealed prominent increases in the number of DNA fragmented cells in both groups when compared to the results before freezing. OAT groups revealed a significantly higher number of DNA fragmented spermatozoa compared to the normospermic group for both time periods.

Conclusion: Cryopreservation produces ultrastructural damage and induces DNA fragmentation in both normospermic and OAT groups. The damage is more severe in the OAT group.
\end{abstract}

Keywords: Cryopreservation, Oligoasthenoteratozoospermia, DNA fragmentation, Ultrastructure

Pınar Turan, Gözde Erkanlı Şentürk, Feriha Ercan (四)

Department of Histology and Embryology, School of Medicine, Marmara University, Basibuyuk, Maltepe, Istanbul, Turkey

e-mail:eferiha@hotmail.com,fercan@marmara.edu.tr

Submitted / Gönderilme: 06.02.2017

Accepted/Kabul: 29.03.2017
ÖZ

Amaç: Oligoastenoteratozoospermi (OAT) erkek infertilitisi sebeplerinden biridir. Kriyopreservasyon infertilite yönetimi için değerlidir. $\mathrm{Bu}$ çalışmanın amacı, OAT'lı hastalarda sperm motilitesi, morfolojisi, ultrastrüktürel detaylar ve DNA fragmentasyonu üzerine kriyopreservasyonun etkilerini ortaya çıkarmaktır.

Gereç ve Yöntem: Bu gözlemsel çalışmada, gönüllü 20

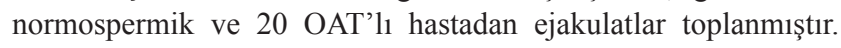
Ejakulatlar, $-196^{\circ} \mathrm{C}$ sıvı nitrojende saklanmış ve çözdürmeden üç ve altı ay sonra analiz edilmiştir. Ejakulatlarda, motilite, morfoloji ve DNA fragmantasyonu dondurma öncesi ve sonrasinda değerlendirilmiştir.

Bulgular: Her iki grupta da sperm motilitesi ve morfolojisi kriyopresvasyondan etkilenmiştir. Her iki grupta da çözdürmeden sonra morfolojik değişiklikler anlamlı artmıştır. Ultrastrüktürel incelemeler membran bütünlüğünün değiştiğini ve akrozomal hasarın arttı̆̆ını göstermiştir. Her iki grupta da, dondurma öncesi ile karşılaştırıldığında, çözdürme sonrasında DNA kırıkları olan hücrelerin arttığı gözlenmiştir. Her iki dondurma-çözme periyodunda, kontrol grubu ile kıyaslandığında OAT grubunda DNA kırıkları olan spermatozoa sayısının anlamlı olarak daha yüksek olduğu gözlenmiştir.

Sonuç: Kriyopreservasyon, hem normospermik hem de OAT gruplarında ultrastrüktürel hasar yapmaktadır ve DNA hasarını indüklemektedir. Bu hasar OAT hastalarında daha ciddidir.

Anahtar kelimeler: Kriyopreservasyon, Oligoastenoteratozoospermi, DNA fragmantasyonu, ultrastrüktür

\section{Introduction}

Sperm cryopreservation is more frequently used in assisted reproductive techniques for the management of infertility. Donor semen is cryopreserved where the reproductive capacities of men with different malignancies will be affected by necessary surgery, radiotherapy or chemotherapy. However, for infertile men with different degrees of oligoasthenoteratozoospermia (OAT), the use of frozen and 
thawed spermatozoa has also been suggested for assisted reproduction [1]. Many of the procedures of cryopreservation produce important functional and morphological changes that reduce the fertilization potential [2]. During the cryopreservation process spermatozoa sustain physical and chemical stresses. It has been reported that the lipid structures of the cell membranes are damaged and this is relevant to the decreased motility and altered morphology of spermatozoa produced by the cryopreservation process $[3,4]$.

Apoptosis balances the generation and reduction of cells during their lifespans. The most significant alterations concerning apoptosis are phosphatidylserine production, DNA fragmentation and the creation of apoptotic structures [3]. Decreased sperm quality, increased DNA fragmentation and mitochondrial dysfunction have been reported in OAT patients [5]. It was also shown that cryopreservationthawing techniques reduced motility, viability and fertilizing ability of sperms in teratospermic patients more than in normospermic men [6]. DNA integrity, morphology and ultrastructure of sperm after cryopreservation-thawing have not been studied in OAT patients with different time periods.

The aim of this study is to evaluate effects of freezing in different time periods on sperm motility, morphology, DNA fragmentation and ultrastructure in OAT and normospermic men.

\section{Materials and Methods}

In this observational study, two groups were formed as normospermic ( $n=20$, mean age 29.1 years), and OAT $(n=20$, mean age 35.6 years) groups. The study was approved by Istanbul No: 2 Clinical Researches Ethical Committee (2009/2530-13, 09.09.2009). Ejaculates were obtained from volunteers. All volunteers gave informed consent prior to participation in the study. All microscopical analysis was done by blind observers.

\section{Selection criteria}

The selection criteria for the normospermic and OAT groups were being between age 25 to 50 years; having no history of any inflammatory, systemic or other diseases that could affect reproductive functions; having no history of testicular injury; not using any medications (medicine for tension pills, kidney diseases, antidepressants, alcohol and smoking etc.); and being normospermic in terms of criteria of the WHO 2010 laboratory manual for the evaluation of human semen [7]. Infertile patients with OAT were selected as follows: having a sperm density of $<15 \mathrm{million} / \mathrm{mL}$; having progressive (PR) and nonprogressive (NP) motility $(\mathrm{PR}+\mathrm{NP})$ of $40 \%$ with a decrease in progression of $32 \%$ and abnormal morphology $<4 \%$. Ejaculates were put into sterile containers after a 3-day sexual abstinence.

\section{Sperm motility}

Sperm motility was evaluated by a light microscopic (Olympus BX51, Tokyo, Japan) observation before freezing and after thawing at 1 or 3 months following the freezing. A Makler Counting Chamber (Sefi Medical Instruments, Haifa, Israel) was used. Sperm motility was labelled as "PR", "NP" or "immotile (IM)" according to WHO 2010 laboratory guidelines.

\section{Sperm freezing and thawing procedures}

We applied the sperm freezing and thawing procedure as described in a previous study [8]. Each ejaculate was divided into three equal parts after a liquefaction process lasting for $45 \mathrm{~min}$ at $37^{\circ} \mathrm{C}$. One part of the ejaculate was evaluated just after the liquefaction. The remaining parts of the ejaculate were frozen for 1 or 3 months respectively, and evaluated after thawing. Semen samples and cryoprotectant (MediCult, Origio, Malov, Denmark: Sperm freezing medium, 10670010) were mixed at the rate of $1: 1$ for the freezing procedure and were collected into cryovials (Simport Scientific, Beloeil, QC, Canada: CryoVial®, T308-2A) with a maximum volume of $1 \mathrm{ml}$. Before being placed in liquid nitrogen $\left(-196^{\circ} \mathrm{C}\right)$, cryovials were kept for 10 $\mathrm{min}$ at room temperature, and for $30 \mathrm{~min}$ in nitrogen vapor. Thawing procedure was carried out at the room temperature for $5 \mathrm{~min}$ after the cryovials were removed from the liquid nitrogen. After thawing of ejaculates, a washing solution (Vitrolife, Englewood, CO, USA: G-Sperm ${ }^{\mathrm{TM}}$ Plus, 10107) was added and the samples were centrifuged at $1200 \mathrm{rpm}$ for $2 \times 10 \mathrm{~min}$. Then, after removal of the cryoprotectant, the superrnatant was collected. After thawing processes, spermatozoa were evaluated for their motility, morphology, DNA fragmentation and ultrastructure.

\section{Histological preparation}

Sperm morphology was evaluated in smear slides stained with Diff-Quick kit (Medion Diagnostics, Gräfelfing, 
Germany) at x100 magnification with a photomicroscope (Olympus BX51, Tokyo, Japan) according to Kruger's strict criteria.

\section{TUNEL assay}

DNA fragmentation was evaluated by a terminal deoxynucleotidyl transferase dUTP nick end labeling (TUNEL) kit (in situ cell death detection kit, Roche Diagnostics $\mathrm{GmbH}$, Mannheim, Germany) in accordance with the manufacturer's guidelines. The air-dried smears were fixed in $4 \%$ paraformaldehyde at room temperature rinsed in phosphate buffered saline (PBS), $\mathrm{pH} 7.4$, and then permeabilized with $2 \%$ Triton X-100. The TdT-labeled nucleotide mixture was added to each slide and incubated in a humidified chamber at $37^{\circ} \mathrm{C}$ for $60 \mathrm{~min}$ in the dark, then rinsed in PBS and counterstained with $10 \mu 1$ 4',6-diamidino2-phenylindole (DAPI) II (Abbott Laboratories, Salt Lake City, UT, USA, 06J50-001). For each slide, approximately 200 cells were analysed with a fluorescence microscope (Olympus BX51, Tokyo, Japan). Each spermatozoon was classified as either a normal (blue nuclear fluorescence due to DAPI II) or fragmented DNA (green nuclear fluorescence). The final percentage of spermatozoa with fragmented DNA was referred to as “\% TUNEL-positive cells" for each sample.

\section{Ultrastructural preparation}

For ultrastructural evaluation, the ejaculates were incubated in a washing solution after liquefaction, centrifuged at 1500 rpm for $10 \mathrm{~min}$ and the supernatant was removed. The resulting pellet was prefixed in $2.5 \%$ glutaraldehyde in 0.1 $\mathrm{M}$ PBS (pH 7.2) at $4^{\circ} \mathrm{C}$ for 4 hours, washed with PBS, postfixed with $1 \% \mathrm{OsO}_{4}(0.1 \mathrm{M}, \mathrm{pH} 7.2)$ for 1 hour, and then processed for routine electron microscopical study. The ultrastructure of the spermatozoa were examined by a JEOL 1200 EXII transmission electron microscope (TEM, Tokyo, Japan) and photographed by a side mounted digital camera (Olympus Morada Soft Imaging System).

\section{Statistical evaluation}

Statistical evaluations were done using GraphPad Prism 5.0 (GraphPad Software, San Diego, CA, USA). Paired Student's t-tests and one-way analysis of variance (ANOVA) tests were used for comparison of normospermic and OAT groups. For all statistical evaluation, all data were calculated as mean \pm standard deviation (SD) and $P<0.05$ was considered significant.

\section{Results}

\section{Motility rate}

According to the $\mathrm{WHO}$ criteria $\mathrm{PR}+\mathrm{NP}$ motility rate was significantly decreased in the OAT group compared to the normospermic group before freezing $(P<0.001)$. PR+NP motility and IM rates were significantly altered in both the normospermic and the OAT groups after thawing for 1 month or 3 months compared to before freezing in the similar time periods respectively $(P<0.001)$. When the 1 month or 3 month post-thaw OAT groups were compared to those of the normospermic group, PR+NP motility rate and IM rate was decreased and increased, respectively (Table I).

\section{Histological evaluation}

In both the normospermic and OAT groups; head, neck, tail and mixed spermatozoa defects relative to normal spermatozoa were observed in pre-freezing, and 1 month and 3 months post-thawing periods (Figure 1). The percentage of normal spermatozoa before freezing was $7.40 \%( \pm 0.27)$ in the normospermic group and $2.10 \%$ $( \pm 0.27)$ in OAT group before freezing. The number of spermatozoa (thawed either 1 month or 3 months later) with normal morphology significantly decreased compared to the pre-freezing group in normospermic and OAT groups $(P<$ 0.001). Post-thawing sperm damage increased significantly in both the normospermic and the OAT groups $(P<0.001$, $p<0.01$, respectively) compared to the pre-freezing groups. Moreover, comparisons of 1 month or 3 months post-thaw OAT groups with those of the normospermic groups showed that rates of normal spermatozoa and abnormal spermatozoa had decreased and increased, respectively (Table I).

\section{Evaluation of DNA fragmentation}

The spermatozoa that contain fragmented DNA were observed as green and normal spermatozoa as blue with florescence microscopy (Figure 2). The rates of DNA fragmentation of spermatozoa were significantly increased in the OAT group $(P<0.001)$ when compared to the normospermic group before freezing. In both normospermic and OAT groups there was a significant increase in the rates of DNA fragmentation of spermatozoa after 1 month (38.35\% and $72.95 \%)$ and 3 


\begin{tabular}{|c|c|c|c|c|c|c|c|c|c|c|c|c|}
\hline & \multicolumn{6}{|c|}{ Motility rate (\%) } & \multicolumn{6}{|c|}{ Morphological defects (\%) } \\
\hline & \multirow{2}{*}{\multicolumn{2}{|c|}{$\begin{array}{l}\text { Before } \\
\text { Freezing }\end{array}$}} & \multicolumn{4}{|c|}{ AfterThawing } & \multirow{2}{*}{\multicolumn{2}{|c|}{ Before Freezing }} & \multicolumn{4}{|c|}{ AfterThawing } \\
\hline & & & \multicolumn{2}{|c|}{ 1st Month } & \multicolumn{2}{|c|}{ 3rd Month } & & & \multicolumn{2}{|c|}{ 1st Month } & \multicolumn{2}{|c|}{ 3rd Month } \\
\hline & $\begin{array}{l}\mathrm{PR}+ \\
\mathrm{NP}\end{array}$ & IM & $\begin{array}{l}\mathrm{PR}+ \\
\mathrm{NP}\end{array}$ & IM & $\begin{array}{l}\mathrm{PR}+ \\
\mathrm{NP}\end{array}$ & IM & Normal & $\begin{array}{c}\text { Abnor- } \\
\text { mal }\end{array}$ & Normal & $\begin{array}{c}\text { Abnor- } \\
\text { mal }\end{array}$ & Normal & $\begin{array}{c}\text { Abnor- } \\
\text { mal }\end{array}$ \\
\hline $\begin{array}{l}\text { Normospermic } \\
\text { group }(n=20)\end{array}$ & $\begin{array}{l}65.62 \\
\pm 2.03\end{array}$ & $\begin{array}{r}34.90 \\
\pm 1.62\end{array}$ & $\begin{array}{l}13.70 \\
\pm 1.80 \\
+++\end{array}$ & $\begin{array}{l}86.10 \\
\pm 1.33 \\
+++\end{array}$ & $\begin{array}{l}5.05 \\
\pm 1.05 \\
+++\end{array}$ & $\begin{array}{l}95.20 \\
\pm 0.86 \\
+++\end{array}$ & $\begin{array}{l}7.40 \\
\pm 0.26\end{array}$ & $\begin{array}{l}92.70 \\
\pm 1.01\end{array}$ & $\begin{array}{l}3.50 \\
\pm 0.21 \\
+++\end{array}$ & $\begin{array}{l}96.20 \\
\pm 1.03 \\
+++\end{array}$ & $\begin{array}{l}3.20 \\
\pm 0.28 \\
+++\end{array}$ & $\begin{array}{l}97.22 \\
\pm 1.24 \\
+++\end{array}$ \\
\hline $\begin{array}{l}\text { OAT group } \\
(\mathrm{n}=20)\end{array}$ & $\begin{array}{l}34.80 \\
\pm 5.31 \\
* * *\end{array}$ & $\begin{array}{l}65.21 \\
\pm 4.04 \\
* * *\end{array}$ & $\begin{array}{l}7.30 \\
\pm \\
2.12 \\
\alpha \alpha \alpha\end{array}$ & $\begin{array}{l}92.25 \\
\pm 1.88 \\
\alpha \alpha \alpha\end{array}$ & $\begin{array}{l}1.70 \\
\pm 0.84 \\
\alpha \alpha \alpha\end{array}$ & $\begin{array}{l}97.80 \\
\pm 0.78 \\
\alpha \alpha \alpha\end{array}$ & $\begin{array}{l}2.10 \\
\pm 0.23 \\
* * *\end{array}$ & $\begin{array}{l}97.95 \\
\pm 1.23 \\
* *\end{array}$ & $\begin{array}{l}0.50 \\
\pm 0.11 \\
\alpha \alpha \alpha\end{array}$ & $\begin{array}{l}99.9 \\
\pm 1.16 \\
\alpha \alpha \alpha\end{array}$ & $\begin{array}{l}0.40 \\
\pm 0.08 \\
\alpha \alpha \alpha\end{array}$ & $\begin{array}{l}99.95 \\
\pm 1.23 \\
\alpha \alpha \alpha\end{array}$ \\
\hline
\end{tabular}

Table I: Sperm motility rate and morphological defects in normospermic and OAT groups. ${ }^{* *} P<0.01,{ }^{* * *} P<0.001$ and ${ }^{+++} P<0.001:$ compared to normospermic group before freezing; ${ }^{\alpha \alpha \alpha} P<0.001$ : compared to OAT group before freezing, PR: progressive, NP: nonprogressive; IM: Immotile. Mean age is 29.1 and 35.6 in normospermic and OAT men, respectively. Values are means \pm SD.

months $(53.60 \%$ and $84.52 \%)$ freezing periods compared to results before freezing $(5.20 \%$ and $58.60 \%, P<0.001)$. On the other hand, there was no statistically significant difference in the rates of DNA fragmentation between the samples of each group that had been frozen for either 1 month or 3 months in both groups. However, comparison of the 1 month or 3 months post-thaw samples of the OAT groups with those of the normospermic group, showed that the rates of DNA fragmentation of spermatozoa were significantly increased $(P$ $<0.001$, Figure 3).

\section{Ultrastructural evaluation}

The spermatozoa in normospermic and OAT groups were evaluated ultrastructurally before freezing and after thawing. Normal spermatozoa with typical head shapes, regular internal and external acrosomal membranes and electron-dense acrosomal ultrastructure were observed more in normospermic than in the OAT groups before freezing (Figure 4). It was also observed that spermatozoa with disturbed head morphology and cytoplasmic residues in the neck region were present in both groups but there were more in the OAT group. Disrupted spermatozoa were more common in the OAT group before freezing. Decreased numbers of normal spermatozoa, a high number of spermatozoa with degenerated acrosome structures, subacrosomal swellings, acrosomal losses, vesicle formation, separation and loss in plasma membrane and chromatin condensation disorders were observed at 1 month or 3 months after freezing in the OAT groups. Moreover, ultrastructural changes were qualitatively quite severe in the OAT group compared to normospermic group after 1 month and 3 months freezing periods.

\section{Discussion}

In the present study, the spermatozoa of normospermic and OAT groups were compared both before freezing and after freezing and thawing regarding sperm motility, histology, DNA fragmentation and ultrastructural features. In both groups, there was a decrease in $\mathrm{PR}+\mathrm{NP}$ motility rate, an increase in structural damage and DNA fragmentation after the freezing and thawing procedures. Number of TUNEL positive cells after the freezing and thawing procedure in the OAT groups at 1 month and 3 months were significantly increased compared to those of the normospermic groups for similar time periods. The ultrastructural examinations qualitatively showed that most of the spermatozoa had membrane disintegration, acrosomal and tail defects in the OAT groups before and after freezing. 
Sperm cryopreservation is wide-ranging clinical application but present procedures are not perfect, and especially semen samples from OAT patients there is an increased vulnerability to cryoinjury [1]. It is also important to demonstrate the ratio of functional sperms after thawing in OAT patients, as it has been reported that sperm from OAT patients have more DNA damage, mitochondrial dysfunction and chromosomal aneuploidy than normospermic men [5].
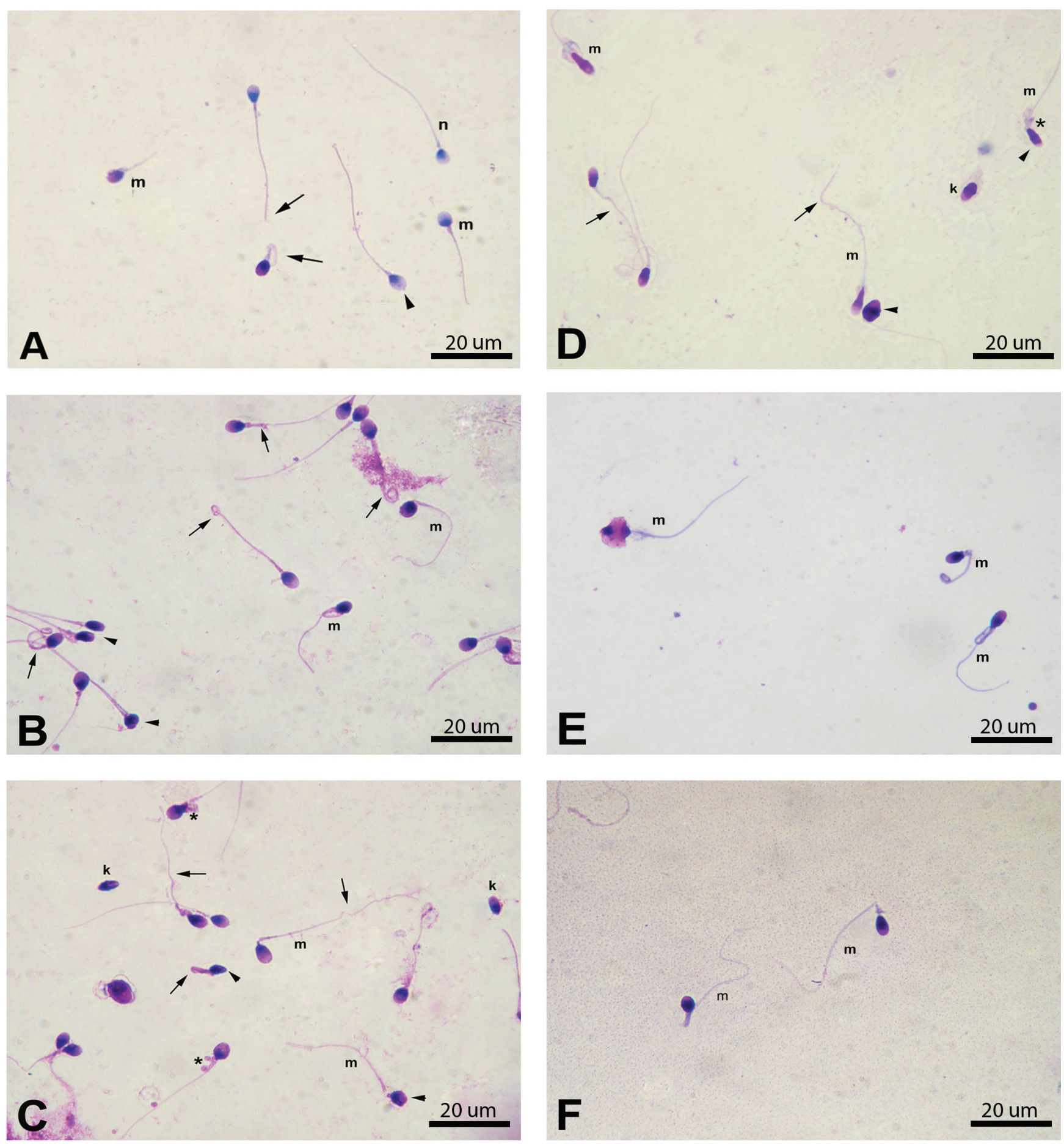

Figure 1. Represantative light micrographs of normospermic group (A, B, C) and OAT group (D, E, F) before freezing (A, D) and thawing after 1 month (B, E) and 3 months (C,F) are seen. Normal spermatozoon (n), head (arrowhead), ruptured head (k), cytoplasmic droplet $(*)$, tail (arrow) and mixed (m) defects are seen in experimental groups. Diff-Quick staining. 
Extracellular and intracellular ice crystal generation, osmotic shock and cellular dehydration have been reported after freezing and thawing of human sperms [9]. Cooling damage can also change the integrity and structure of cellular membranes $[10,11,12]$. Both the plasma membranes and the mitochondrial membranes have this sensitivity to cryopreservation [13]. A modification of the liquidity of membranes of mitochondria may also cause a modification in mitochondrial membrane potentials and the release of reactive oxygen species [14].
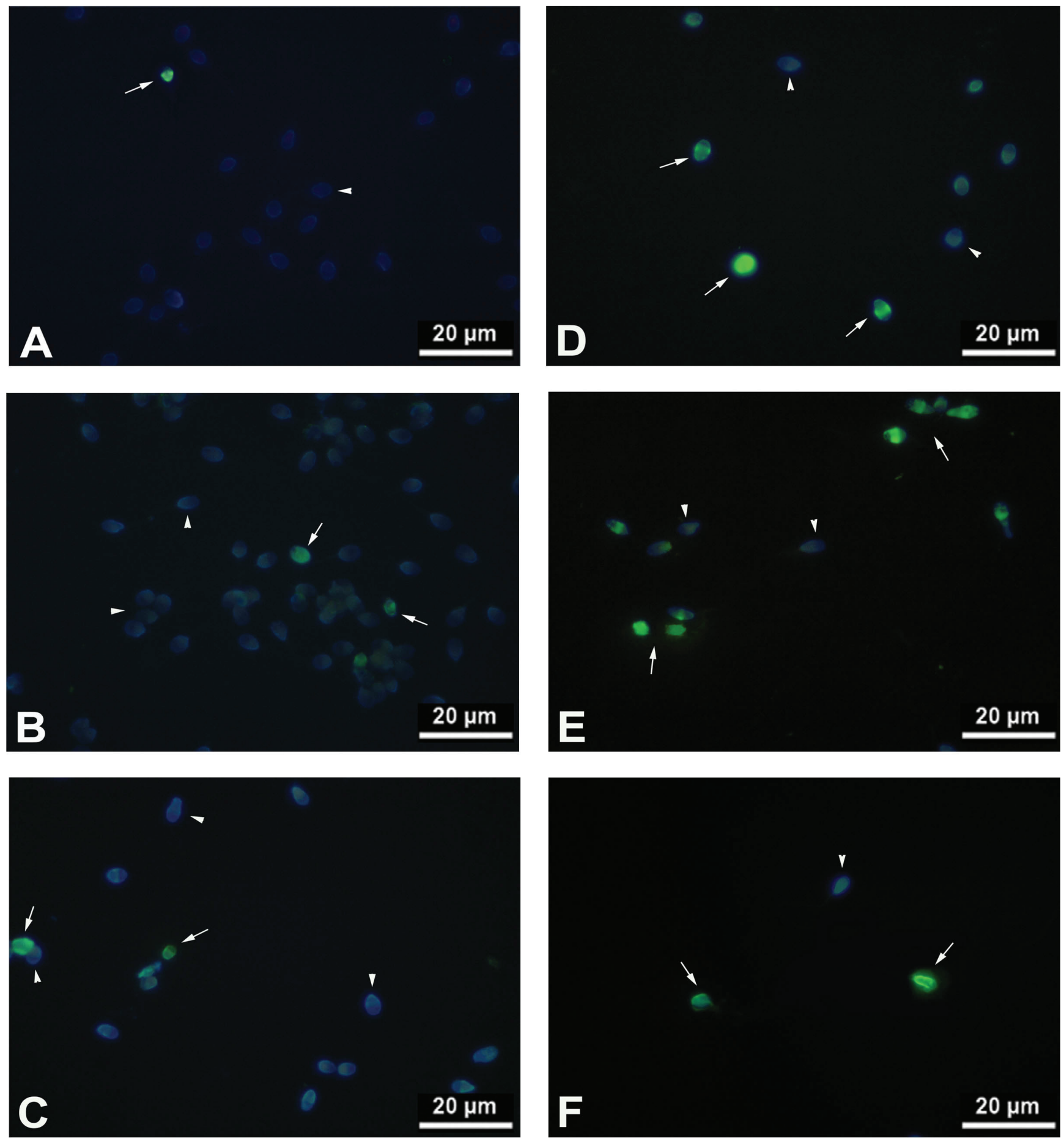

Figure 2. Represantative light micrographs of DNA fragmented spermatozoa of normospermic group (A, B, C) and OAT group (D, E, F) before freezing (A, D) and thawing after 1 month (B, E) and 3 months (C, F). TUNEL-positive sperms (green) (arrow) and TUNELnegative sperm (blue) (arrowhead) are seen in experimental groups. TUNEL kit and DAPI II staining. 


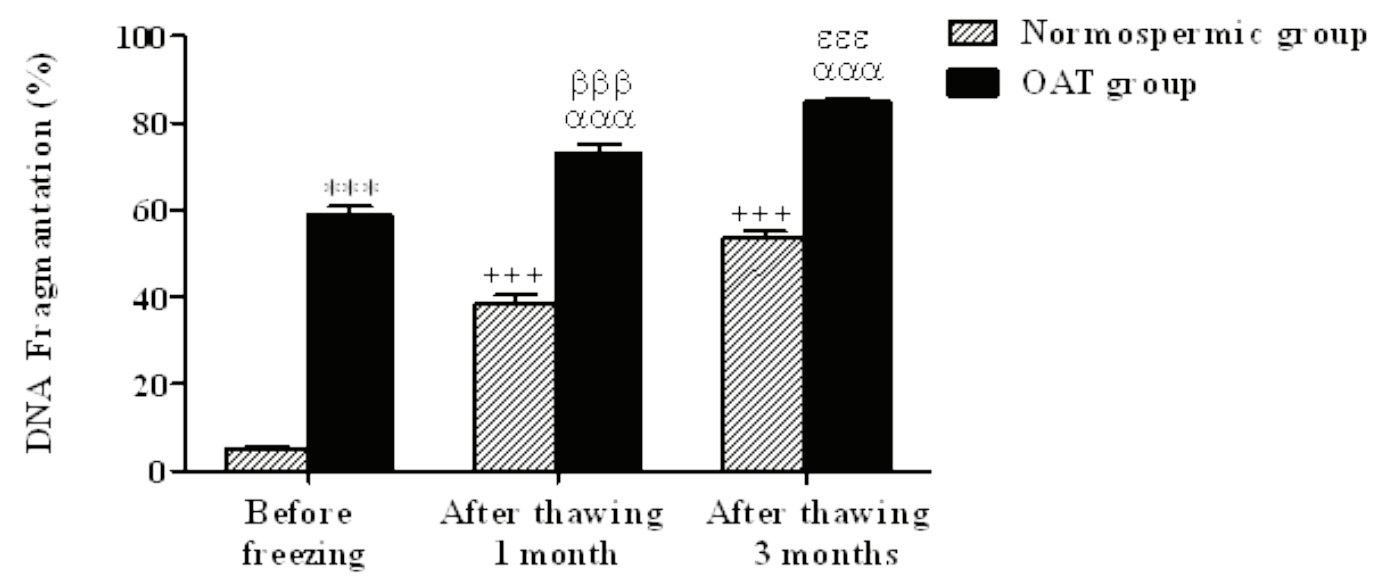

Figure 3. Assessment of DNA fragmented cells ratio. ${ }^{* * *} P<0.001$ and ${ }^{+++} P<0.001$, compared to normospermic group before freezing; ${ }^{\alpha \alpha \alpha} P<0.001$, compared to OAT group before freezing; ${ }^{\beta \beta \beta} P<0.001$, compared to normospermic group thawing after 1 month, ${ }^{\varepsilon \varepsilon \varepsilon} P<0.001$, compared to normospermic group thawing after 3 months.

The peroxidative impairment induced by increased concentrations of reactive oxygen species is related to the detoriation of the axonemal structure and damage to the spermatozoa membrane [15]. It has also been shown that cryopreservation reduces the antioxidant activities of the spermatozoa, making them more sensitive to reactive oxygen injuries [16]. Elevated concentrations of reactive oxygen species and decreases of antioxidant enzymes cause cell death after cryopreservation [17, 18]. It has been reported that normospermic samples have higher levels of polyunsaturated fatty acids than do oligospermic and asthenospermic samples and that the total antioxidant capacity was higher in normospermic samples than the oligospermic and oligoastenospermic groups before freezing. It was described that the fatty acid constitution of the spermatozoa or seminal plasma has been described as directly related to sperm viability and motility after freezing and thawing [19].

It has been reported that cryopreservation causes structural disorganisation such as spiral tails, degenerated acrosome and plasma membranes [20], cell death and reduced numbers of vital spermatozoa [21]. Cryopreservation also causes an increase in DNA damage [22]. In the present study we have observed a reduction in numbers of normal spermatozoa and an elevation in abnormal spermatozoa having head, neck or tail defects in both the normospermic and OAT groups thawed after 1 or 3 month-long freezing periods. The number of spermatozoa with multiple signs of damage was increased in both groups after thawing. Sperm with normal morphology and sperm with abnormal head morphology, with a disorganised chromatin condensation or cytoplasmic residues in the neck region were observed in the ultrastructural material fixed before freezing.

It had earlier been shown that cryopreservation induces subacrosomal and acrosomal swelling and vesiculation, as well as separation in the cellular membranes [23, 24]. Parallel to this, we also saw that sperm with degenerated acrosomal structures, vesicle formation and loss of the acrosome, subacrosomal swellings, detoriation of plasma membranes and disturbed mitochondrial organisation in the neck region. In an earlier study, similar ultrastructural alterations were also observed after thawing in samples from fertile smoker volunteers [8].

In our study, there were significant increases in multiple head damage in the OAT groups compared to normospermic groups after thawing by light and electron microscope levels. This indicated that the degeneration of membrane, chromatin and acrosome were more severe in the OAT groups. Ultrastructural studies showed injury mechanisms related to spermatozoa in OAT patients after thawing.

Stability of the DNA content of the spermatozoa is definitely crucial due for the paternal contribution to fertilization and for avoiding early embryonic death [25] and the normal progression of the pregnancy [26]. It has been reported that, oxidative stress leads to degeneration of cellular membranes and impairs the DNA integrity of spermatozoa. Damage to DNA caused by reactive oxygen species expedites the death of spermatozoa [27]. In the present study, we detected the DNA fragmentation of spermatozoa by the TUNEL method before freezing, and 

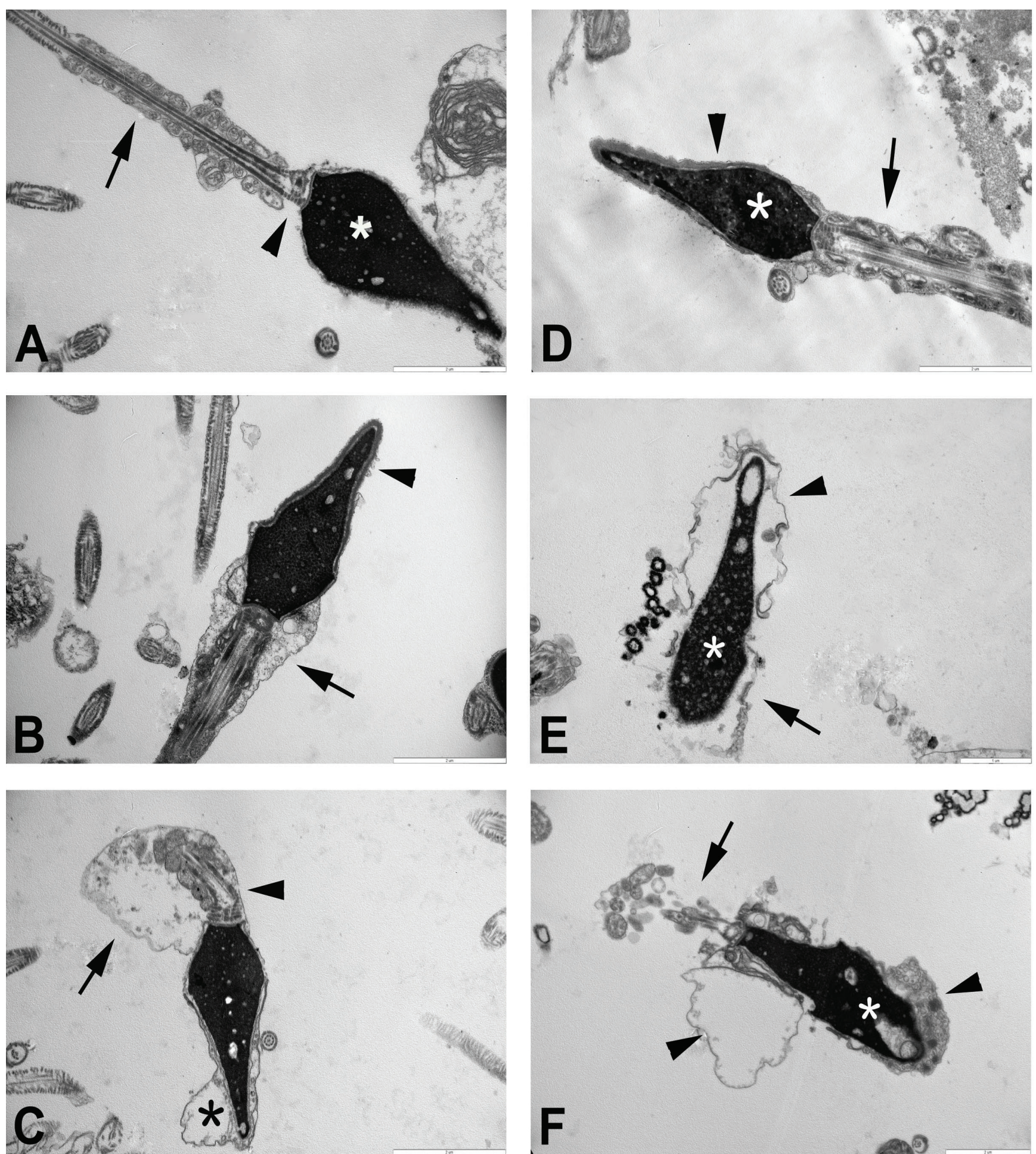

Figure 4. Represantative transmission electron micrographs of normospermic group (A, B, C) and OAT group (D, E, F) before freezing (A, D) and thawing after 1 month (B, E) and 3 months (C, F). (A) Normal spermatozoon with entire head (*), neck (arrowhead), and midpiece structure (arrow) before freezing; (B) rather normal spermatozoon with entire head (arrowhead), neck (arrow), and membranes thawing after 1 month; (C) disintegration of membranes of acrosome $(*)$, degenerated neck (arrowhead) and tail (arrow) thawing after 3 months in normospermic group. (D) Normal spermatozoon with entire head (*), acrosome (arrowhead), membranes and midpiece ultrastructure (arrow) before freezing; (E) disintegration of chromatin condensation (*), acrosomal swelling (arrowhead) and degeneration of membranes (arrow) thawing after 1 month; $(\mathrm{F})$ vacuole formation in head $(*)$, acrosomal swelling and degeneration (arrowhead), degenerated mitochondria (arrow) and loss of membranes with tail defect thawing after 3 months in OAT group. 
after thawing at 1 month and 3 month in the normospermic and OAT groups. There was a significantly higher DNA fragmentation rate in the OAT groups compared to normospermic groups before the freezing procedure. This is probably due to altered oxidant/antioxidant composition of semen/spermatozoa of the OAT patients.

Seminal plasma preserves the sperm from adverse factors such as oxidative stress, although these protective effects were altered in infertile patients [28]. However, seminal plasma has also been shown to contain cells such as aging sperms, leukocytes and epithelial cells that can generate reactive oxygen species and can lead to oxidative and apoptotic injury during the freezing and thawing procedure [14]. Another study reported that sperm selection by density gradient centrifugation before freezing allows the selection of a better functional sperm population with more resistance to the cryopreservation processes [29]. In the present study, we used spermatozoa obtained by density gradient centrifugation and washing to eliminate the leukocytes and epithelial cells that might produce oxidative stress. However, an increase in rates of DNA fragmentation was statistically significant in the thawed sperms of both normospermic and OAT groups after the 1 and 3 months freezing periods. This might be due to increases in the impairment of spermatozoa morphology and membrane permeability caused by physical and chemical stress based on cryopreservation. For both the 1 month and 3 months freezing periods, DNA fragmentation in the OAT group was more severe than the corresponding normospermic groups. Approximately, $70 \%$ of spermatozoa after 1 month and $85 \%$ of spermatozoa after 3 months freezing in the OAT group were TUNEL-positive. These results should be related with storing of spermatozoa in artificial chilling condition, and it made spermatozoa of OAT patients more sensitive than the normospermic men. These results demonstrate that the freezing and thawing process and the period of freezing are critical to save functional sperm populations in OAT patients.

\section{Conclusion}

Cryopreservation causes DNA fragmentation and damage in sperm ultrastructure of both normospermic and OAT groups; however these results were more severe in the OAT group. In order to detect abnormalities of spermatozoa, use of histochemical and electron microscopic techniques supply more elaborate results than the use of routine histological techniques. The severe decrease in functional sperms and the increase in DNA fragmentation following cryopreservation in the OAT group compared to the normospermic group after 1 month and 3 months freezing indicates that improved methods are needed. The mechanisms of DNA fragmentation after cryopreservation techniques in sub fertile men should also be studied in detail so that assisted reproduction can be more effective. New techniques are needed for cryopreservation of sperm from OAT patients. For minimizing the formation of physical and chemical stresses on sperm structure during cryopreservation, the method needs to be improved by the use of chemical agents such as antioxidants that prevent the formation of reactive oxygen species.

\section{Acknowledgements}

This study was financially supported by Marmara University Scientific Research Committee (SAG-C-YLP-211009-0311, SAG-C-TUP-211009-0312). The authors wish to thank Dr. Dilek AKAKIN for her helpful suggestions and Prof. Ray GUILLERY for language editing of our manuscript. The authors report no conflicts of interest.

\section{References}

1. Oehninger S, Duru NK, Srisombu C, Morshedi M. Assessment of sperm cryodamage and strategies to improve outcome. Mol Cell Endocrinol 2000; 169:3-10. doi: 10.1016/ S0303-7207(00)00343-9

2. Anger JT, Gilbert BR, Golstein M. Cryopreservation of sperm: indications, methods and results. J Urol 2003; 170(4 Pt1):1079-84. doi: 10.1097/01.ju.0000084820.98430.b8

3. Glander HJ, Schaller J. Binding of annexin V to plasma membranes of human spermatozoa: a rapid assay for detection of membrane changes after cryostorage. Mol Hum Reprod 1999;5:109-15. doi: 10.1093/molehr/5.2.109

4. Schiller J, Arnhold J, Glander HJ, Arnold K. Lipid analysis of human spermatozoa and seminal plasma by MALDITOF mass spectrometry and NMR spectroscopy - effects of freezing and thawing. Chem Phys Lipids 2000; 106: 145-56. doi: 10.1016/S0009-3084(00)00148-1

5. Liu $\mathrm{CH}$, Tsao HM, Cheng TC, et al. DNA fragmentation, mitochondrial dysfunction and chromosomal aneuploidy in the spermatozoa of oligoasthenoteratozoospermic males. J Asist Reprod Genet 2004; 21: 119-26. doi: 10.1023/B:JARG.0000029495.22787.83

6. Kalthur G, Adiga SK, Upadhya S, Rao S, Kumar P. Effect of cryopreservation on sperm DNA integrity in patients with teratospermia. Fertil Steril 2008; 89: 1723-7. doi: 10.1016/j. fertnstert.2007.06.087

7. World Health Organisation. WHO laboratory manual for the examination and processing of human semen, 5th ed. Geneva, Switzerland: WHO Press, 2010. 
8. Aydin MS, Senturk GE, Ercan F. Cryopreservation increases DNA fragmentation in spermatozoa of smokers. Acta Histochem 2013; 115: 394-400. doi: 10.1016/j. acthis.2012.10.003

9. Stanic P, Tandara M, Sonicki Z, Simunic V, Radakovic B, Suchanek E. Comparison of protective media and freezing techniques for cryopreservation of human semen. Eur J Obstet Gyn Reprod Biol 2000; 91: 65-70. doi: 10.1016/ S0301-2115(99)00255-9

10. Zeron Y, Pearl M, Borochow A, Arav A. Kinetic and temporal factors influence chilling injury to germinal vesicle mature bovine oocytes. Cryobiology 1999; 38: 35-42. doi: 10.1006/ cryo.1998.2139

11. Giraud MN, Motta C, Boucher D, Grizard G. Membrane fluidity predicts the outcome of cryopreservation of human spermatozoa. Human Reprod 2000; 15: 2160-4. doi: 10.1093/ humrep/15.10.2160

12. Quinn PJ. A lipid-phase separation model of low-temperature damage to biological membranes. Cryobiology 1985; 22: 128-46. doi: 10.1016/0011-2240(85)90167-1

13. O'Connell M, McClure N, Lewis SE. The effects of cryopreservation on sperm morphology, motility and mitochondrial function. Human Reprod 2002; 17: 704-9. doi: 10.1093/humrep/17.3.704

14. Said TM, Gaglani A, Agarwal A. Implication of apoptosis in sperm cryoinjury. Reprod BioMed Online 2010; 21: 456-62. doi: 10.1016/j.rbmo.2010.05.011

15. Saleh RA, Agarwal A. Oxidative stress and male infertility: from research bench to clinical practice. J Androl 2002; 23: 737-52.

16. Lasso JL, Noiles EE, Alvarez JG, Storey BT. Mechanism of superoxide dismutase loss from human sperm cells during cryopreservation. J Androl 1994; 15: 255-65.

17. Gadea J, Molla M, Selles E, Marco MA, Garcia-Vazquez FA, Gardon JC. Reduced glutathione content in human sperm is decreased after cryopreservation: effect of the addition of reduced glutathione to the freezing and thawing extenders. Cryobiology 2011; 62: 40-6. doi: 10.1016/j. cryobiol.2010.12.001

18. Di Santo M, Tarozzi N, Nadalini M, Borini A. Human sperm cryopreservation: Update on techniques, effect on DNA integrity, and implications for ART. Adv Urol 2012; 2012: 854837. doi: 10.1155/2012/854837

19. Martínez-Soto JC, Landeras J, Gadea J. Spermatozoa and seminal plasma fatty acids as predictors of cryopreservation success. Andrology 2013; 1: 365-75. doi: 10.1111/j.20472927.2012.00040.x

20. Check ML, Check JH, Long R. Detrimental effects of cryopreservation on structural and functional integrity of the sperm membrane. Arch Androl 1991; 27: 155-60.

21. Paasch U, Sharma RK, Grupta AK, et al. Cryopreservation and thawing is associated with varying extent of activation of apoptotic machinery in subsets of ejaculated human spermatozoa. Bio Reprod 2004; 71: 1828-37. doi: 10.1095/ biolreprod.103.025627

22. Zribi N, Chakroun NF, Euch HE, Gargouri J, Bahloul A, Keskes LA. Effects of cryopreservation on human sperm deoxyribonucleic acid integrity. Fertil Steril 2010; 93: 15966. doi: 10.1016/j.fertnstert.2008.09.038

23. Nogueira D, Bourgain C, Verheyen G, Van Steirteghem AC. Light and electron microscopic analysis of human testicular spermatozoa and spermatids from frozen and thawed testicular biopsies. Hum Reprod 1999; 14: 2041-9. doi: 10.1093/humrep/14.8.2041

24. Ozkavukcu S, Erdemli E, Işık A, Oztuna D, Karahuseyinoglu S. Effects of cryopreservation on sperm parameters and ultrastructural morphology of human spermatozoa. J Assist Reprod Genet 2008; 25: 403-11. doi: 10.1007/s10815-0089232-3

25. Evenson DP, Jost LK, Marshall D, et al. Utility of the sperm chromatin structure assay as a diagnostic andrognostic tool in the human fertility clinic. Hum Reprod 1999; 14: 1039-49. doi: 10.1093/humrep/14.4.1039

26. Agarwal A, Saleh RA, Bedaiwy MA. Role of reactive oxygen species in the pathophysiology of human reproduction. Fertil Steril 2003; 79: 829-43. doi: 10.1016/S00150282(02)004948-8

27. Aitken RJ, De Luliis GN, McLachlan RI. Biological and clinical significance of DNA damage in the male germ line. Int J Androl 2009; 32: 46-56. doi: 10.1111/j.13652605.2008.00943.x

28. Desai N, Sharma R, Makker K, Sabanegh E, Agarwal A. Physiologic and pathologic levels of reactive oxygen species in neat semen of infertile men. Fertil Steril 2009; 92: 162631. doi: 10.1016/j.fertnstert.2008.08.109

29. Brugnon F, Ouchchane L, Pons-Rejraji H, Artonne C, Farigoule M, Janny L. Density gradient centrifugation prior to cryopreservation and hypotaurine supplementation improve post-thaw quality of sperm from infertile men with oligoasthenoteratozoospermia. Hum Reprod 2013; 28: 204557. doi: 10.1093/humrep/det253 